\title{
DNA マーカーを用いたもち米加工品からのうるち米の検出
}

\author{
井伊悠介*，足立静香 \\ 独立行政法人農林水産消費安全技術センター神戸センター
}

DNA Markers Detecting Non-glutinous Rice in Glutinous Rice Processed Food

Yusuke Ii* and Shizuka Adachi

Food and Agricultural Materials Inspection Center, Kobe Regional Center, 1-3-7 Minatozimaminamimachi, Chuo-ku, Kobe, Hyogo 650-0047

\begin{abstract}
To facilitate authentic food labeling, primer sets were constructed to detect contamination with non-glutinous rice in glutinous rice processed foodstuffs. Primers for two DNA markers were designed, because each glutinous rice cultivar has either 23-bp duplication or a 7764-bp insert in the Wx gene. Single PCR products were generated using primer set F12-R14-R15, with a 163-bp fragment obtained from non-glutinous rice, and 138-bp and 186-bp fragments from glutinous rice, due to the presence of the 23-bp duplication. A 190-bp PCR product was generated with primer set F22-R05 from non-glutinous rice, whereas this fragment was not obtained from glutinous rice, which harbors the 7764-bp insert. The PCR detection rates of non-glutinous rice with these DNA markers were evaluated using mixed DNA from rice cakes made in our laboratory. The PCR detection methods exhibited a $100 \%$ detection rate at the following sensitivities. F12-R14-R15 detected non-glutinous rice content at levels exceeding $2.5 \%$, in samples containing glutinous rice with the 23-bp duplication. F22-R05 detected non-glutinous rice content at levels above $1.0 \%$, in samples containing glutinous rice with the 7764-bp insert. Commercial products were analyzed, and as a result, these DNA markers were amplified from their DNA. Here, we have demonstrated that these primer sets might be useful for detection of non-glutinous rice in glutinous rice processed foods, made from glutinous rice having either the 23-bp duplication or the 7764-bp insert.

(Received Apr. 26, 2013 ; Accepted Jul. 24, 2013)
\end{abstract}

Keywords : DNA marker, PCR, food labeling, glutinous rice, non-glutinous rice キーワード : DNA マーカー, PCR, 食品表示, うるち米，もち米

うるち米やもち米から上新粉や白玉粉のような米粉, さ らには団子や餅といった米加工品が製造される。もち米や 白玉粉を主に使ったもち米加工品には道明寺粉やおはぎの ようなものがあり, 原材料名の表示や「もち米ヒヨクモ千 $100 \%$ 使用」等の特色ある原材料の表示は消費者の商品選 択の情報の一つである。

農林物資の規格化および品質表示基準の適正化に関する 法や不当景品類および不当表示防止法では原材料について 適切な表示を求めている.

しかし, 原材料米としてもち米しか表示されていないも ち米加工品において，もち米以外に加工用米や特定米穀等 の安価なうるち米も原材料に用いている場合, 目視等によ るその製品の外観の観察からではうるち米が使われている かの判断は困難である。よってうるち米混入の検出方法の 開発が求められる.

近年, 加工食品の原材料等を検知する DNA マーカーが

于650-0047 兵庫県神戸市中央区港島南町 1-3-7

*連絡先 (Corresponding author), yuusuke_ii@nm.famic.go.jp
報告されている1) ${ }^{1)}$. DNA マーカーによるもち米加工品の 原材料判別法の報告(7)7 ${ }^{6 あ}$ はが，もち米の数品種のみや異 種の穀類の検出を目的としており，うるち米の検出の検討 は見受けられない.

うるち米と異なり，もち米にはアミロース合成に関与す る $W x$ 遺伝子の第 2 エキソンに $23 \mathrm{bp}$ 重複 899 , 第 9 エキソ ンにレトロトランスポゾン様の $7764 \mathrm{bp}$ の挿入 ${ }^{10)}$ による変 異配列が存在している（以下，これらの変異をそれぞれ 23D 変異および TP 変異とする。またこれらの変異を持つ もち米をそれぞれ 23D 変異型もち米および TP 変異型も ち米とする)，岸根・奥西 ${ }^{11}$ はこれらの変異配列をそれぞ れ特異的に増幅するプライマーセットを設計し，日本のも ち米 48 品種の $W x$ 遺伝子の変異が $23 \mathrm{D}$ 変異もしくは $\mathrm{TP}$ 変異のいずれかであることを報告している。また，うるち 米の DNA 溶液に 23D 変異型もち米もしくは TP 変異型も ち米の DNA が 0.5-20\%になるように混合した DNA 溶液 を用いて PCR を行い，もち米の DNA が $0.5 \%$ の場合にお いても上記のプライマーセットによる PCR 産物を確認し 
ている ${ }^{11}$.

このプライマーセットを改変することで，うるち米が混 入しているもち米加工品について, その原材料もち米が, 23D 変異型もち米または TP 変異型もち米のいずれか 1 種 類のみならば，うるち米の混入が検知可能と考えられる.

具体的には，23D 変異型もち米にうるち米が混入してい る場合は, $23 \mathrm{D}$ 変異の両外側に結合するプライマーセット を用いた PCRにより，23D 変異型もち米とうるち米から それぞれ PCR 増幅が生じるが，23D 変異を持たないうる ち米の PCR 産物は $23 \mathrm{D}$ 変異型もち米の $\mathrm{PCR}$ 産物より 23 $\mathrm{bp}$ 短い.また TP 変異型もち米にうるち米が混入してい る場合は, TP 変異の両外側に結合するプライマーセット を用いた PCRにより，うるち米から TP 変異配列を含ま ない短い PCR 産物が生じる。これらの PCR 産物の確認に よりうるち米の混入が判断できる.

ただし PCR 増幅において，うるち米と TP 変異型もち 米が鋳型の場合には $23 \mathrm{D}$ 変異配列を挟み込むプライマー セットからの PCR 産物長はそれぞれ同じであり，またう るち米と 23D 変異型もち米が鋳型の場合には TP 変異を 挟み込むプライマーセットの PCR 産物長もそれぞれ同じ である.よってこの 2 種類の変異のもち米が混合された場 合は，異なる $W x$ 遺伝子の米の混入は判断できるが，うる ち米の使用については判断できない.このことから本研究 ではどちらか 1 種類の変異型もち米へのうるち米の混入を 想定して，もち米加工品からのうるち米のスクリーニング 的な検出方法を検討した.

\section{実 験 方 法}

\section{1. 試料および DNA 抽出}

精米試料として，各品種について原料玄米が単一原料米 である精米を市場で購入した（括弧内は等級別品位基準に よる等級を示す)。23D 変異型もち米は「ヒヨクモチ」(1 等級と 2 等級の混合)，「こがねもち」(1 等級)，「風の子も ち」(1 等級),「はくちょうもち」(1 等級),「たつこもち」 ( 2 等級),「きたゆきもち」(1 等級) および「きぬのはだ」 ( 1 等級) の 7 品種, $\mathrm{TP}$ 変異型もち米は「ヒメノモチ」(1 等級と 2 等級の混合）および「わたぼうし」（1 等級）の 2 品種，うるち米は「日本晴」(1 等級) および「ミルキーク イーン」（2等級以上）を用いた。もち米の変異と品種の対 応は岸根・奥西 ${ }^{11)}$ による（「きたゆきもち」を除く）。餅の 模擬試料を $23 \mathrm{D}$ 変異型もち米, $\mathrm{TP}$ 変異型もち米およびう るち米ごとに, ざるに入れて水道水で洗浄し, 室温で 30 分 静置して水を切った後に水と混合して，ホームベーカリー SD-BMS102（パナソニック）を用いて「もち」メニューに より作製した。洗浄前の精米 $280 \mathrm{~g}$ に対して水を $180 \mathrm{~mL}$ （うるち米の場合は $240 \mathrm{~mL}$ ) になるように加えた。模擬試 料は 1 ロット作製した。

またこの模擬試料とは別に，273 g のもち米精米にうる
ち米精米を $7 \mathrm{~g}$ 加え，水を $180 \mathrm{~mL}$ 用いて上記と同様の方 法により，うるち米が $2.5 \%$ 混合された餅の模擬試料を 1 ロット作製した。なお，この試料はもち米として 23D 変 異型もち米と TP 変異型もち米をそれぞれ用いることで, 合計 2 種類を用意した。

さらに，本分析法の市販品への適用性の確認のために， もち加工品 12 点（桜餅 4 点, おはぎ 3 点, 大福 3 点, よも ぎもち 1 点および越前餅 1 点）を市場で購入し供試した.

精米試料, 模擬試料および市販品から， 100-150 mg を採 取し DNeasy Plant Mini Kit（キアゲン）により DNA を抽 出した。市販品においてはできるだけもちの部分のみを採 取するようにした，RNaseA を加えた後に，藤田ら ${ }^{12)}$ の方

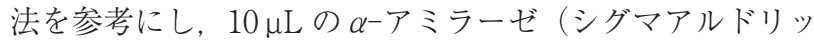
チ）および $20 \mu \mathrm{L}$ の proteinase $\mathrm{K}$ (キアゲン) を添加し $65^{\circ} \mathrm{C}$ で 1 時間以上加温する操作を追加した。抽出 DNA は，分 光光度計 NanoDrop 1000 (サーモフィッシャーサイエン ティフィック）により測定された $260 \mathrm{~nm}$ の吸光度から DNA 濃度を算出した後に， AE バッファー（キアゲン）に より $5 \mathrm{ng} / \mu \mathrm{L}$ に希橎した。

\section{2. プライマーの設計}

$23 \mathrm{D}$ 変異型もち米に混入したうるち米を検知するプラ イマーとして，フォワードプライマーF12（5'-GCTAGACAACCACCATGTCGGCTCTCA-3’ ; GenBank accession no. AB281458）および2 種類のリバースプライマーR14（5' ACGCTGAGCGACGTCGCGTC-3' ; GenBank accession no. AB281458）およびR15（5’ -CCCTGGAACCCGTGGGCTTGA-3' ; GenBank accession no. AB281458）を作製した. $\mathrm{F} 12$ および R14 は $23 \mathrm{bp}$ の重複の変異部位を挟むように設 計し， R15 は岸根・奥西 ${ }^{11}$ を参考にして変異部位内に設計 した（図 1A）。TP 変異型もち米に混入したうるち米を検 知するプライマーとして, フォワードプライマー F22（5' GAAGATCAACTGGATGAAGGCCGGAATC-3’ ; GenBank accession no. AB268120）およびリバースプライマー R05 (5' -CTAGGATCCCACTCGCTGACGTCCA-3' ; GenBank accession no. AB268120）を作製した. F22 およびR05 は 7 $764 \mathrm{bp}$ の挿入の変異部位を挟むように設計した（図 1B）. また，もち米およびうるち米で $104 \mathrm{bp}$ を増幅する PCR コ ントロールプライマーセットとしてフォワードプライマー F34 (5' -CACTTCTCTGCTTGTGTTGTTCTGTTGTTCA3'；GenBank accession no. AB281432）およびリバースプ ライマーR35（5'-GTGATCGATCTGAATAAGAGGGGAAACAAAGAAT-3’ ; GenBank accession no. AB281432) を作製した。

\section{PCR 反応および電気泳動}

うるち米と $23 \mathrm{D}$ 変異型のもち米を識別するための PCR 反応液は, 0.4 U KOD FX NEO (東洋紡), $1 \times$ KOD FX NEO Buffer, $0.5 \mu \mathrm{M}$ の F12 プライマーおよびR14 プライ マー, $0.25 \mu \mathrm{M}$ の R15 プライマー, $0.4 \mathrm{mM}$ dNTP, $10 \mathrm{ng}$ 
A

TGCAGAGATCTTCCACAGCAACAGCTAGACAACCACCATGTCGGCTCTCAC

CACGTCCCAGCTCGCCACCTCGGCCACCGGCT T CGGCATCG C CGACAGGT

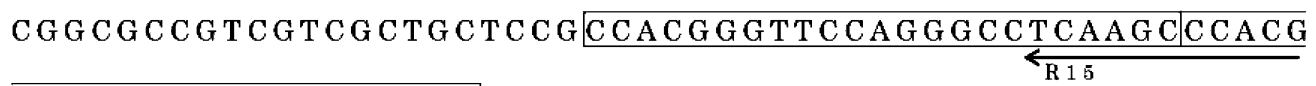

$\underline{\underline{\text { GGTTCCAGGGCCTCAAGC }} \mathrm{CCCGCAGCCCCGCCGGCGGCGACGCGACGTC}}$

G C T CAGCGT GA C GA C C A G C G C G CG C G C GA

B

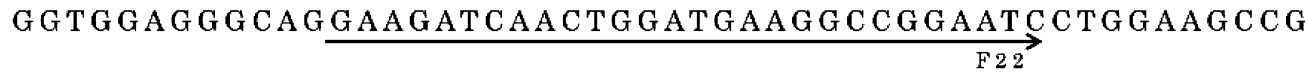
ACAGGGTGCTCACCGTGAGCCCGTACTACGCCGAGGAGCTCATCT C CGGC

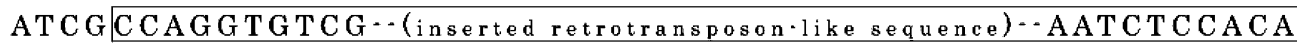

C CAGGGGATGCGAGCTCGACAACATCATGCGGCTCACCGGCATCACCGGC

ATCGTCAACGGCATGCAACGGCATGGACGTCAGCGAGTGGGATCCTAGCA

図 1 うるち米ともち米を識別する DNA マーカーのプライマー部位

(A) 23D 変異型もち米とうるち米を識別する DNA マーカーの配列．四角で囲まれた $23 \mathrm{bp}$ が $23 \mathrm{D}$ 変異型もち米では重複している. 矢印はプライマー部位を示す.

(B) TP 変異型もち米とうるち米を識別する DNA マーカーの配列。四角で囲まれた領域は $7764 \mathrm{bp}$ の挿入配列であり, TP 変異型もち米に存在している。矢印はプライマー部位を示す。

の鋳型 DNA および滅菌水を混和し, $20 \mu \mathrm{L}$ に調製した。 うるち米と $\mathrm{TP}$ 変異型のもち米を識別するための $\mathrm{PCR}$ 反 応液は, 0.4 U KOD FX NEO（東洋紡），1×KOD FX NEO Buffer, $0.5 \mu \mathrm{M}$ の F22 プライマーおよびR05 プライマー, $0.25 \mu \mathrm{M}$ の F34 プライマーおよび R35 プライマー, $0.4 \mathrm{mM}$ dNTP, $10 \mathrm{ng}$ の鋳型 DNA および滅菌水を混和し, $20 \mu \mathrm{L}$ に調製した。

$\mathrm{PCR}$ 反応は, $95^{\circ} \mathrm{C}$ で 4 分間変性後, $98^{\circ} \mathrm{C}$ で 10 秒, $68^{\circ} \mathrm{C}$ で 25 秒を 35 サイクル行った。 PCR 産物は，核酸染色剂とし てゲルレッドを含む $3 \%$ アガロースゲルを用いて TBE バッファーによる電気泳動により分離した。

\section{実験結果および考察}

F12-R14-R15 プライマーセットについては，TP 変異型 もち米およびうるち米では $23 \mathrm{bp}$ の重複変異部位を持たな いことから R15 は結合せず，F12 と R14による $163 \mathrm{bp} の$ 増幅が期待された（図 1A）。23D 変異型もち米では F12

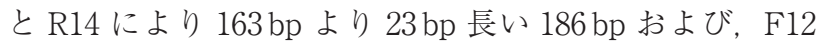
と変異配列下流に結合した R15により $138 \mathrm{bp}$ の増幅が期 待された（図 $1 \mathrm{~A}$ )。23D 変異型もち米 7 品種と $23 \mathrm{bp}$ の重 複変異を有しない $\mathrm{TP}$ 変異型もち米 2 品種およびうるち米 2 品種の精米からの抽出 DNA を用いて PCR を行ったと
ころ，23D 変異型もち米では $138 \mathrm{bp}$ および $186 \mathrm{bp}$ が，TP 変異型もち米およびうるち米では $163 \mathrm{bp}$ の PCR 産物が確 認されたことから（図 2A）, このプライマーセットにより $23 \mathrm{D}$ 変異型もち米とこの変異を持たない $\mathrm{TP}$ 変異型もち米 およびうるち米が判別できると考えられた。なお「きたゆ きもち」の変異は，岸根・奥西 $\left.{ }^{11}\right)$ の報告にないことから, 彼 らの PCR 条件に従って調査したところ $23 \mathrm{D}$ 変異と判断さ れたことから（データ未掲載），23D 変異型もち米として 扱った。 なお，この変異の識別は F12 および R14 プライ マーの 2 種類でも可能であるが，23D 変異型もち米とうる ち米の混合試料を用いて事前に検討したところ，R15 プラ イマーも加えた場合の方が $163 \mathrm{bp}$ と $186 \mathrm{bp}$ の分離がより 短時間で可能だったことから (データ未掲載), 3 種類のプ ライマーを用いることとした。

F22-R05 プライマーセットについては，23D 変異型もち 米およびうるち米は $190 \mathrm{bp}$ の PCR 産物が生じるが, TP 変異型もち米はこれらのプライマーで挟まれた領域内に 7 $764 \mathrm{bp}$ の挿入部位 ${ }^{10)}$ があることから，この長さの PCR 産 物は増幅しないと予想された（図 1B)。また,この PCR 産 物が観察されなかった場合，試料が TP 変異型もち米であ るためか PCR 反応の失敗であるためかの判断が困難なこ とから PCR 反応のコントロールプライマーセットを設計 


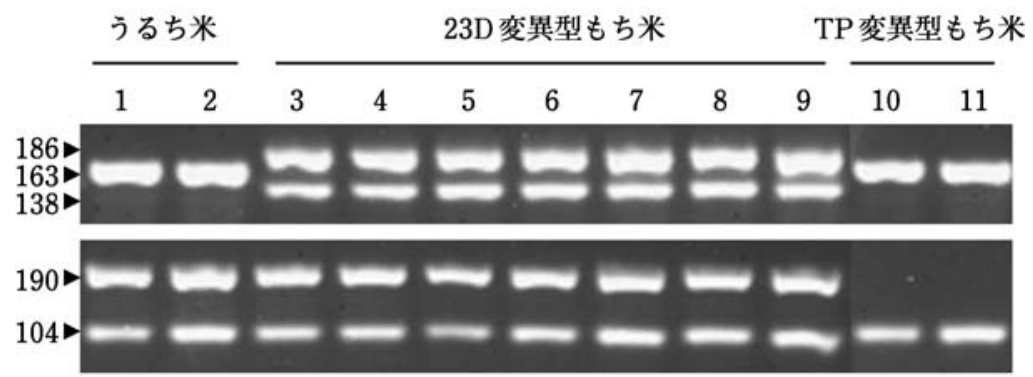

図 2 うるち米およびもち米の精米の抽出 DNA からの F12-R14-R15 プライマーセットおよび F22R05 プライマーセットにより増幅された PCR 産物

1 日本晴, 2 ミルキークイーン, 3 ヒヨクモチ, 4 こがねもち， 5 風の子もち，6 はくちょう

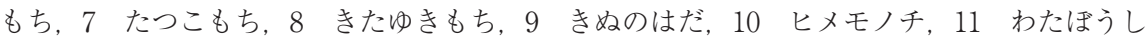

(A) F12-R14-R15 プライマーセットによる PCR 産物.

(B) F22-R05 プライマーセットによる PCR 産物（190 bp） および PCR コントロールプライマーセッ ト F34-R35による PCR 産物（104 bp）。

した。 $\mathrm{TP}$ 変異を有しない $23 \mathrm{D}$ 変異型もち米 7 品種および うるち米 2 品種と $\mathrm{TP}$ 変異型もち米 2 品種の精米からの抽 出 DNA により, F22-R05 プライマーセットおよび PCR コ ントロールプライマーセットによるマルチプレックス PCRを行った。 23D 変異型もち米およびうるち米では F22-R05 プライマーセットおよび PCR コントロールプラ イマーセットからの PCR 産物が確認され, TP 変異型もち 米では F22-R05 プライマーセットからの PCR 産物が観察 されない一方で PCR コントロールプライマーセットから の PCR 産物が確認されたことから（図 2B）, これらのプラ イマーセットにより TP 変異型もち米とこの変異を持たな い23D 変異型もち米およびうるち米が判別できると考え られた。本研究でうるち米の一つとして用いたミルキーク イーンは低アミロース米の一つであり，Wx 遺伝子の 2 箇 所における 1 塩基ずつの変異が報告されている ${ }^{13}$. 低アミ ロース米も米加工品に使用する場合もあることから用い た。ミルキークイーンの変異は $23 \mathrm{D}$ 変異や $\mathrm{TP}$ 変異では ないので, F12-R14-R15 プライマーセットおよび F22-R05 プライマーセットによるPCRの結果は日本晴と同様に なったと考えられた。

23D 変異型もち米, TP 変異型もち米およびうるち米か らそれぞれ作製した模擬試料からの DNA を段階的に混合 したDNA 溶液（以下, 混合 DNA 溶液とする）を調製し, うるち米の PCR 増幅産物が確認できる濃度について調査 した．混合 DNA 溶液に含まれる DNA 量の比をうるち米 /もち米で 0.5/99.5，1.0/99.0，2.5/97.5，5.0/95.0 および 7. 5/92.5 とし，23D 変異型もち米とうるち米および $\mathrm{TP}$ 変異 型もち米とうるち米についてそれぞれ作製した。

$23 \mathrm{D}$ 変異型もち米およびうるち米の混合 DNA 溶液を用 いて F12-R14-R15 プライマーセットによる PCR を実施し たところ，うるち米と $23 \mathrm{D}$ 変異型もち米の DNA が含まれ る混合 DNA 溶液では 23D 変異型もち米に由来する $138 \mathrm{bp}$ および $186 \mathrm{bp}$ およびうるち米に由来する $163 \mathrm{bp}$ の PCR
A

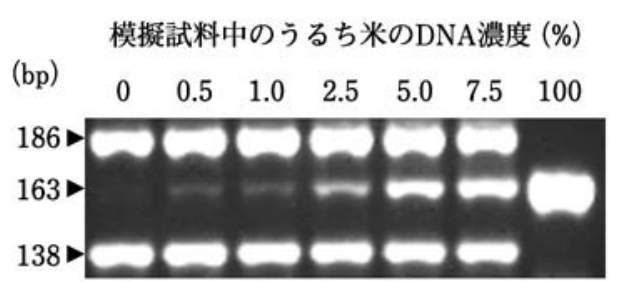

B

模擬試料中のうるち米のDNA浱度 (\%)

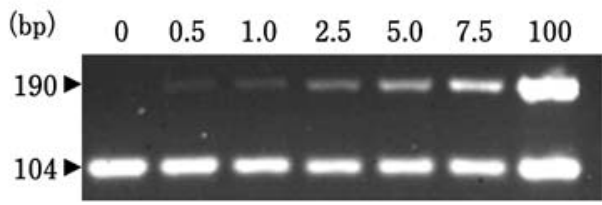

図 3 うるち米およびもち米の模擬試料の混合 DNA 溶液か らの F12-R14-R15 プライマーセットおよび F22-R05 プライマーセットにより増幅された PCR 産物

(A) F12-R14-R15 プライマーセットによる PCR 産物。もち 米として23D 変異型もち米を用いた。

(B) F22-R05 プライマーセットによる PCR 産物（190 bp） もち米として TP 変異型もち米を用いた. $104 \mathrm{bp}$ は PCR コントロールプライマーセットによる PCR 産物である.

産物が確認された（図 3A)。うるち米の DNAのみでは $163 \mathrm{bp}$ が, 23D 変異型もち米のみだと $138 \mathrm{bp}$ および $186 \mathrm{bp}$ が増幅された。うるち米の DNA が $2.5 \%$ 以上の混合 DNA 溶液で安定して $163 \mathrm{bp}$ の PCR 産物が確認された（表 1 ）.

$\mathrm{TP}$ 変異型もち米およびうるち米の混合 DNA 溶液を用 いて F22-R05 プライマーセットおよび PCR コントロール プライマーセットによる PCR を実施したところ，全ての 試料で PCR コントロールプライマーセットによる PCR 産 物が確認された。うるち米の DNA を含む混合 DNA 溶液 ではうるち米に由来する PCR 産物が確認された（図 3B). うるち米の DNA が $1.0 \%$ 以上の混合 DNA 溶液で安定し 
表 1 F12-R14-R15 プライマーセットによる模擬試料中の うるち米の検知結果

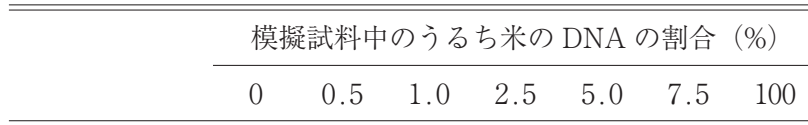

検知数/分析数 $0 / 24 \quad 14 / 24 \quad 20 / 24 \quad 24 / 24 \quad 24 / 24 \quad 24 / 24 \quad 24 / 24$

$\begin{array}{llllllll}\text { 検知率 }(\%) & 0 & 58 & 83 & 100 & 100 & 100 & 100\end{array}$

模擬試料のもち米には, $W x$ 遺伝子の第 2 エキソンに $23 \mathrm{bp}$ の 重複変異 ${ }^{899}$ を持つもち米を用いた。

検知率 $(\%)=($ 検知数 $/$ 分析数 $) \times 100$

表 2 F 22-R05 プライマーセットによる模擬試料中のうる ち米の検知結果

\begin{tabular}{|c|c|c|c|c|c|c|c|}
\hline & \multicolumn{7}{|c|}{ 模擬試料中のうるち米の DNA の割合（\%） } \\
\hline & 0 & 0.5 & 1.0 & 2.5 & 5.0 & 7.5 & 100 \\
\hline 斤数 & $0 / 17$ & $11 / 17$ & $17 / 17$ & $17 / 17$ & $17 / 17$ & $17 / 17$ & $17 / 17$ \\
\hline 検知率 (\%) & 0 & 65 & 100 & 100 & 100 & 100 & 100 \\
\hline
\end{tabular}

模擬試料のもち米には, $W x$ 遺伝子の第 9 エキソンに $7764 \mathrm{bp}$ の挿入変異 ${ }^{10)}$ を持つもち米を用いた

検知率 $(\%)=($ 検知数 $/$ 分析数 $) \times 100$
プライマーセット

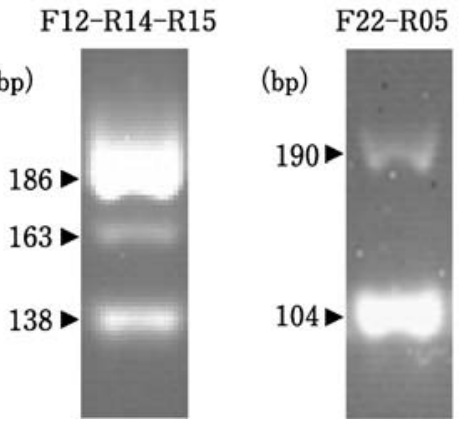

図 4 精米の段階で $2.5 \%$ のうるち米が混合された模擬試料 から抽出した DNA からの F12-R14-R15 プライマー セットおよび F22-R05 プライマーセットにより増幅さ れた PCR 産物

(A) うるち米の混入率が $2.5 \%$ である $23 \mathrm{D}$ 変異型もち米から 作製した模擬試料

(B) うるち米の混入率が $2.5 \%$ である TP 変異型もち米から 作製した模擬試料（104 bp は PCR コントロールプライ マーセットによる PCR 産物である）

A

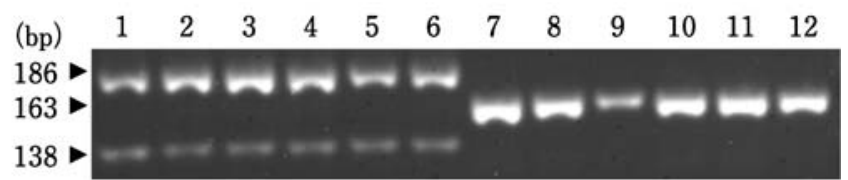

B

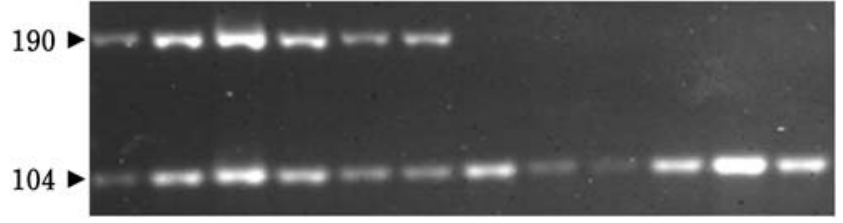

図 5 市販のもち加工品からの抽出 DNA からの F12-R14-R15 プライマーセットおよび F22-R05 プライマーセットから増幅された PCR 産物

1 桜餅， 2 おはぎ， 3 越前もち，4 おはぎ， 5 桜餅，6 おはぎ， 7 桜餅， 8 桜餅,

9 大福, 10 よもぎもち, 11 大福, 12 大福

(A) F12-R14-R15 プライマーセットによる PCR 産物

(B) F22-R05 プライマーセットによる PCR 産物（190 bp). 104 bp は PCR コントロールプ ライマーセットによる PCR 産物である

て F22-R05 プライマーセットによる PCR 産物が確認され た (表 2). うるち米の DNA 量の増加に伴い, うるち米の DNA の PCR 産物量も増加した（図 $3 \mathrm{~A}$ および図 3B）。岸 根 ·奥西 ${ }^{11}$ はもち米の DNA 量の増加ともち米検出マー カーの PCR 産物量に強い増幅が認められたことから, 高 い特異性をもつマーカーと判断しており, 本研究のマー カーも高い特異性を持つと考えられた。また，精米の段階 でうるち米を $2.5 \%$ 混合した餅の模擬試料を分析した結 果, $23 \mathrm{D}$ 変異型もち米から作製した餅および $\mathrm{TP}$ 変異型も ち米から作製した餅のどちらにおいてもうるち米由来の PCR 産物が確認された（図 4)。このことから，実際にうる ち米が含まれている製品からそれを検知できる可能性が示
唆された

市販品 12 点を分析した結果， 6 製品では $186 \mathrm{bp}$ と 138 bp の F12-R14-F15 プライマーセットによる PCR 産物（図 5A のレーン 1-6）および F22-R05 プライマーセットによ る PCR 産物（図 5B のレーン 1-6）が確認されたことから, $23 \mathrm{D}$ 変異型もち米のみの使用が推定された。残りの 6 製 品では $163 \mathrm{bp}$ のの F12-R14-R15 プライマーセットによ る PCR 産物が確認された（図 5A のレーン 7-12）一方で F22-R05 プライマーセットによる PCR 産物が確認されな かったことから（図 5B のレーン 7-12），TP 変異型もち米 のみの使用が推定された。なお 12 製品全てで PCR コント ロールプライマーセットによる PCR 産物が確認された(図 
5B). これらの結果から本分析方法は市販のもち米加工品 に適用できると考えられた

米の品種判別法として SNPs を利用した DNA マーカー によりうるち米やもち米の日本の 205 品種を識別する報 告 ${ }^{14)}$ があるが，複数品種が混合された米加工品における使 用品種の特定は困難と考えられる。本法は原材料米の品種 の識別には利用できないが，原材料もち米が 23D 変異型 もち米もしくは TP 変異型もち米のいずれかであるもち米 加工品についてうるち米の混入を, 上記の方法 ${ }^{14)}$ より安価 で簡便に利用できるスクリーニング的な方法と考えられた。

\section{要約}

もち米加工品におけるうるち米の混入を検知する DNA マーカーについて研究を行った. もち米はその品種により $W x$ 遺伝子に $23 \mathrm{bp}$ の重複変異配列か $7764 \mathrm{bp}$ の挿入変異 配列を持つことから，もち米とうるち米を識別するプライ マーをそれぞれのもち米の変異配列ごとに設計した，次に もち米とうるち米との混合試料を作製し，検知可能なうる ち米量を調査した。 $W x$ 遺伝子に $23 \mathrm{bp}$ の重複変異配列を 持つもち米とうるち米を用いた場合には，うるち米の混入 率が $2.5 \%$ 以上の場合，検知率は $100 \%$ であった。 Wx 遺 伝子に $7764 \mathrm{bp}$ の挿入変異配列を持つもち米とうるち米を 用いた場合，うるち米の混入率が $1.0 \%$ 以上の場合，検知 率は $100 \%$ であった。市販の製品を分析したところ，これ らの抽出 DNA から DNA マーカーが増幅された。これら のことから本研究の DNA マーカーは, もち米加工品の原 材料もち米の変異が 1 種類の場合においてうるち米の混入 の確認に有用であると考えられ，さらに市販のもち米加工 品を分析し, 市販品にも適用できることが確認された。

\section{文献}

1) Iguchi, J., Takashima, Y., Namikoshi, A. and Yamashita, M., Species identification method for marine products of Seriola and related species. Fish. Sci., 78, 197-206 (2012).

2）岸根雅宏，奥西智哉，米粉パン中の米粉割合推定のための 競合的 PCR 法の利用，日本食品科学工学誌，59, 616-620
(2012).

3) Nagase, M., Maeta, K., Aimi, T., Suginaka, K. and Morinaga, $\mathrm{T}$., Analytical methods for quantification of relative flying fish paste content in processed sea food (ago-noyaki). Food Sci. Technol. Res.,16, 703-408 (2011).

4) Namikoshi, A., Takashima, Y., Iguchi, J., Yanagimono, Y. and Yamashita, M., Species identification of Alaska Pollock, Gadus spp., and Micromesistius spp. in cod roe products using a PCR-based method. Fish. Sci., 77, 671-678 (2011).

5) Tanabe, S., Hase, M., Yano, T., Sato, M., Fujimura, T. and Akiyama, H., A Real-Time Quantitative PCR detection method for pork, chicken, beef, mutton, and horseflesh in foods. Biosci. Biotechonol. Biochem., 71, 3131-3135 (2007).

6）大坪研一，中村澄子，興座宏一，宍戸功一，餅を試料とする 原料米の DNA 品種判別, 日本食品科学工学会誌, 76 306-310 (2001)

7）中村澄子, 鈴木啓太郎，原口和朋，興座宏一，奥西智哉，松 井崇晃，石崎和彦，吉井洋一，大坪研一，糯加工品における 糯米の品種判別および異種穀類の混入検出技術の開発， 日 本食品科学工学会誌, 78, 984-993 (2004).

8) Inukai, T., Sako, A., Hirano, H. and Sano, Y., Analysis of intragenic recombination at $w x$ in rice: Correlation between the molecular and geneteic maps within the locus. Genome, 43, 589-896 (2000).

9) Wanchana, S., Toojinda, T., Tragoonrung, S. and Vanavichit, A., Duplicated coding sequence in the weaxy allele of tropical glutinous rice (Oryza sativa L.). Plant Science, $\mathbf{1 6 5}$, 1193-1199 (2003)

10) Hori, Y., Fujimoto, R., Sato, Y. and Nishio, T., A novel $w x$ mutation caused by insertion of a retrotransposon-like sequence in a glutinous cultivar of rice (Oryza sativa). Theor. Appl. Genet., 115, 217-224 (2007).

11）岸根雅宏，奥西智哉，DNA マーカーによる糯米検出法，日 本食品科学工学会誌, 58, 26-29 (2011).

12）藤田由美子, 村上恭子, 原口浩幸，市販キットを用いたコム ギ加工食品からの DNA 抽出法の比較, 日本食品科学工学 会誌, 59, 414-421 (2012).

13） Sato, H., Suzuki, Y., Sakai, M. and Imbe, T., Molecular Characterization of $W x-m q$, a nonel mutant gene for lowamylose content in endosperm of rice (Oryza sativa L.) Breed. Sci., 52, 131-135 (2002)

14) Sato, H., Endo, T., Shiokai, S., Nishio, T. and Yamaguchi, M. Identification of 205 current rice cultivar in Japan by dotblot-SNP analysis. Breed. Sci., 60, 447-453 (2010).

(平成 25 年 4 月 26 日受付, 平成 25 年 7 月 24 日受理) 